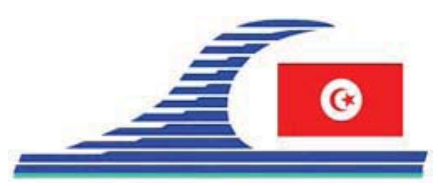

Conférence Méditerranéenne Côtière et Maritime EDITION 1, HAMMAMET, TUNISIE (2009)

Coastal and Maritime Mediterranean Conference

Disponible en ligne - http://www.paralia.fr-Available online

\title{
TAPARURA PROJECT: Sustainable coastal development, including the decontamination and rehabilitation of the coastal area of the city of Sfax, Tunisia
}

\author{
Bart CALLAERT ${ }^{1}$, Jan VAN DEN BOGAERT ${ }^{1}$, Alain PIETERS ${ }^{1}$, \\ Kris PYNAERT ${ }^{1}$, Pierre TISON ${ }^{2}$, Kurt LEVRAU ${ }^{2}$, \\ Dave VANDER HEYDE ${ }^{2}$, Daphné GLASER ${ }^{3}$
}

1. Envisan N.V., International Department Belgium, Tragel 60, 9308 Hofstade-Aalst, Belgium.info@envisan.com

2. Jan De Nul N.V. Belgium, Tragel 60, 9308 Hofstade-Aalst, Belgium. info@jandenul.com

3. Envisan France S.A.S., 12, place Saint-Hubert, 59000 Lille, France.

info@envisan.com

\section{Summary:}

The ecological aspects in port planning and the sustainable development of areas around the port is a major concern of all people involved in planning, development and construction.

The Taparura Project is a typical example, and is part of a wider action program put together by the Tunisian authorities to tackle the primary sources of pollution in the region.

The project is situated along the harbour of Sfax, and includes the rehabilitation of a former complex industrial site (Fig. 1), the clean-up of beaches (Fig. 2) and restoration of the area (Fig. 3).

One of the main objectives is the sustainable development of the Mediterranean coastal area in front of the city.

Keywords:

Rehabilitation - Phosphor gypsum - Environmental dredging - Contaminated sediments
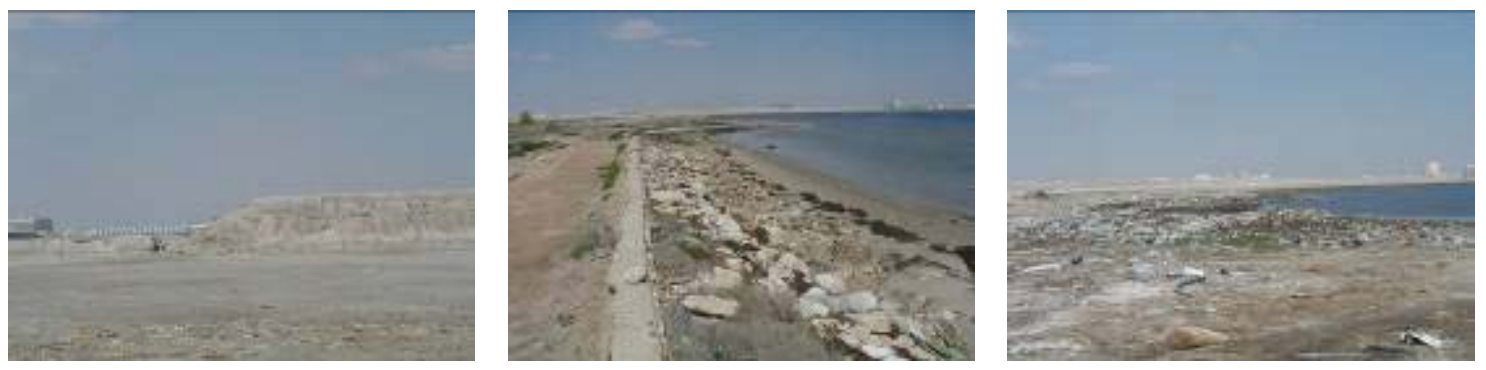

Figures 1-2-3. A look around the coastline before the start of the rehabilitation.

DOI: 10.5150/cmcm.2009.044-2 


\section{Location and historical background of the pollution}

Sfax is a city in Tunisia, located $270 \mathrm{~km}$ southeast of Tunis. The city, founded in AD 849 on the ruins of Taparura and Thaenae, is the capital of the Sfax governorate, and a Mediterranean port on the Gulf of Gabes, a gulf on Tunisia's east coast in the Mediterranean Sea. The gulf is 100 kilometers long and wide, with the Kerkena Islands on the northeast and Djerba Island on the southeast. It has a large tidal range, 2.0 meters at spring tides.

Sfax has a population of 340000 inhabitants, and is an industrial centre for processing phosphates. The city is often described as Tunisia's second city, because only Tunis has more inhabitants. The port is the largest in the country, and specializes in exporting phosphates from big mining complexes in the region.

For many years the coastal area (approximately 150 hectares) adjacent to the harbour (Figures1-2-3) has been affected with pollution from various types of solid and liquid wastes. Phosphor gypsum, the residue from phosphate treatment, has been stored in an uncontrolled manner along the coastline, with a surface of approximately 50 hectares and a height of 6 meters above the sea level.

Pollution from this site was threatening the beaches and coastal waters of Sfax, hampering further development and economical growth, such as tourism.

\section{The Presidential project}

The Taparura project forms part of a global action program put together by the Tunisian authorities to tackle the sources of pollution and to improve the overall environment of the Sfax region. The project promoter is the Tunisian Ministry for Infrastructure and Housing (the actual client is called "Société d'Etude et d'Aménagement des Côtes Nord de la Ville de Sfax"; an autonomous government company under supervision of the Ministry for Infrastructure and Housing), which will continue its policy of pollution abatement and development of public and private industrial parks.

The beach and landfill restoration will create a mixed space for new public and private activities, such as beaches, parks, sports grounds, educational, health and museum infrastructure, as well as the implementation of social housing programs.

\section{Environmental studies and feasibility studies}

Different studies (Fig. 4) executed during the nineties saw several samples being taken both on land and in the seabed. The planners were emphasizing a reconciliation of the city with its littoral by creating beaches and a new urban area, largely reclaimed from the sea to extend the city.

The main problem was what to do with the complex industrial site, the phosphate dump of approximately $3000000 \mathrm{~m}^{3}$. The solution that was ultimately selected is to create a central piece in the whole area; a pyramidal looking park covering a total area of approximate 55 ha. 


\section{Financing the project}

The project obtained the backing of the European Investment Bank (EIB) and EIB contributed approximately $50 \%$ of the financing. The other $50 \%$ of the financing was contributed through export credit facilities sourced from Belgium (25.5 M€) and France ( $8 \mathrm{M} €$ ) inclusive of $35 \%$ concessionality and a direct commercial loan of $6 \mathrm{M} €$.

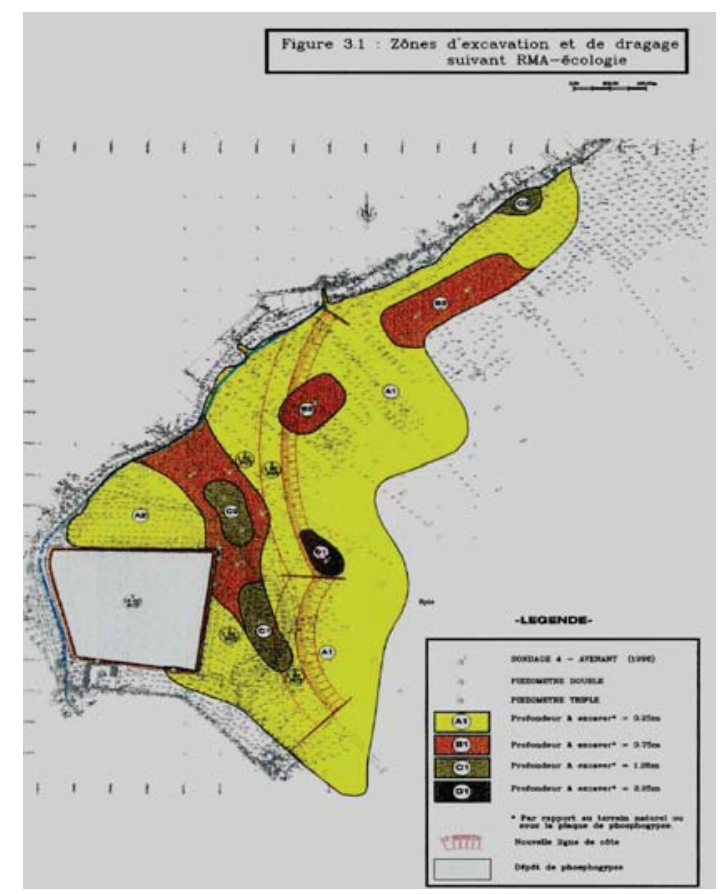

Fig 4. Final study.

Excavation and dredging plan.

\section{Execution}

On 30 March 2006, the Joint venture Jan DE NUL - ENVISAN - SOMATRA signed a contract for the remediation and the rehabilitation of the entire site. The Joint Venture was awarded the contract based on its competitive price and capability to offer a solution on a short notice. The project consists of different stages:

A detailed site investigation (on- and offshore), (Fig. 5).

The excavation of approximately 1.7 million $\mathrm{m}^{3}$ on land, including $1300000 \mathrm{~m}^{3}$ of phosphate plate around the toe of the landfill (Fig. 6).

Dredging of approximate $500000 \mathrm{~m}^{3}$ contaminated sediments below sea level, with a water depth of approximate 0.5 to 1.5 meter (Figures 7-8). All wet polluted material is stockpiled and dewatered in a special designated area, on top of the existing landfill.

The rehabilitation of this pyramidal phosphate dome comprises the reshaping of the slopes, the installation of a vertical bentonite-HDPE screen along the perimeter in order to create a confined area, including the installation of a cover layer with land-based material and a new topsoil layer (Fig. 9). 
The remediated area will be reclaimed with 6.15 million $\mathrm{m}^{3}$ of sand, dredged by means of Trailer suction hopper dredgers (Fig. 10) with material sourced at a distance of approximately $18 \mathrm{~km}$.

The whole period for the contract is set at 2.5 years with an approximate project value of $73.5 \mathrm{M} €$.

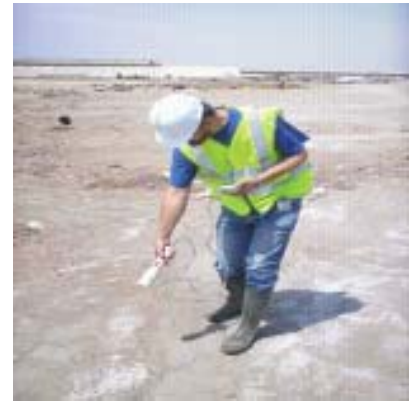

Figure 5.

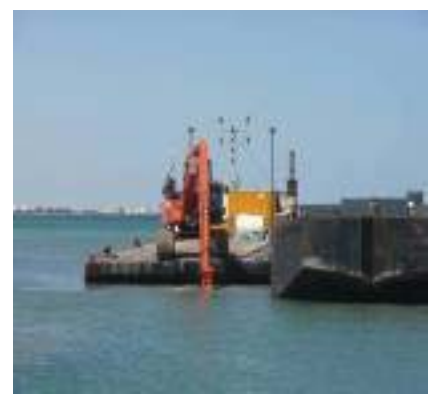

Figure 8.

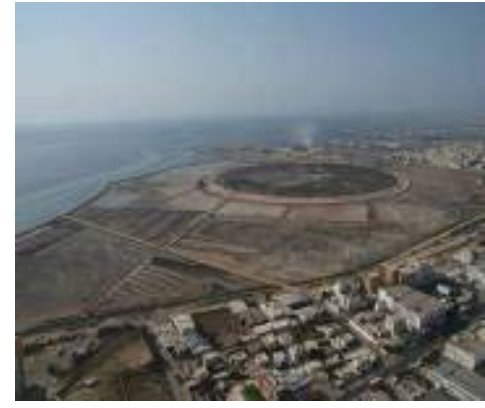

Figure 6.

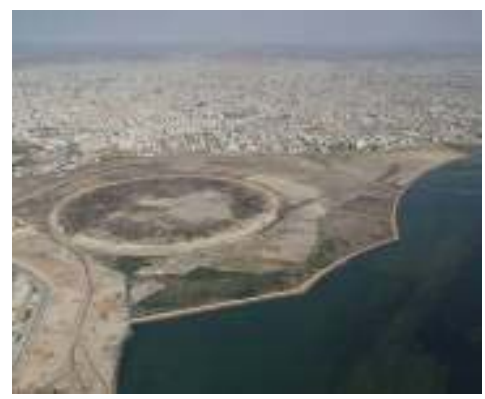

Figure 9.

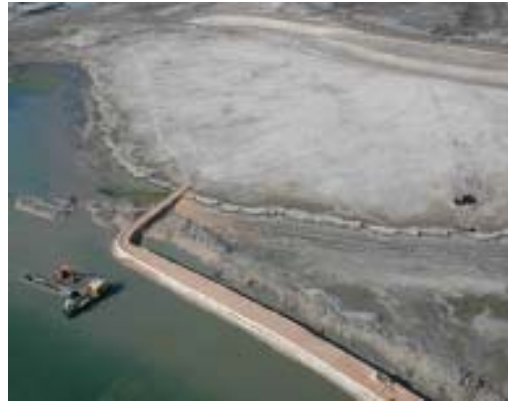

Figure 7.

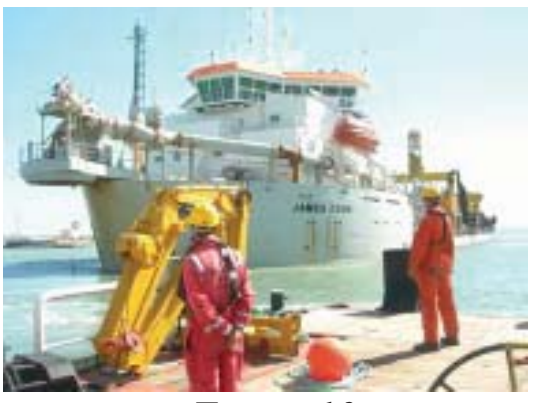

Figure 10.

\section{Actual situation and end of the remediation works}

Currently the project is approaching the end. The underwater contamination has been removed and the land remediation has been finalized. The installation of the cover layer is finished. The reclamation of the remediated site and the confinement of the phosphor gypsum area have been finished too.

\section{Conclusion}

The ecological aspects in port planning and the sustainable development of areas around the port is a major concern for all. A complex multidisciplinary project such as Taparura is a challenge for all people involved: planners, financers, engineers, environmentalist, contractors, consultants, authorities and many more.

The execution of the project (2.5 years - 2006-2008) is only a fraction of the total lifespan of the project (20 years - 1990-2010). However, the benefit for the community and the city of Sfax will last through the coming century. 